\title{
A Bibliometric Analysis and Visualisation of Research Trends in Surface Modification of knee Implants
}

\section{Bhupinder Singh}

Department of Mechanical Engineering, Chandigarh University, Gharuan, Punjab, India. 140413

Article History: Received: 11 January 2021; Accepted: 27 February 2021; Published online: 5 April 2021

\begin{abstract}
Several metals are used for Knee implants. The bibliometric analysis had been conducted to understand the active authors, organizations, journals, and countries involved in the research domain of "Surface modification of knee implants". All published articles related to "Surface modification of knee implants" from "Scopus", were analyzed using the VOS viewer to develop analysis tables and visualization maps. This article had set the objective to consolidate the scientific literature regarding "Surface modification of knee implants"." and also to find out the trends related to the same. The most active journals in this research domain were Journal of Arthroplasty and Journal of Bone and Joint Surgery. The most active country was the United States of America. The leading organization engaged in research regarding surface modification of knee implants was the Hospital for Special Surgery of the United States of America. The most active authors were Wright T.M. and Jacobs J.J.
\end{abstract}

Keywords: knee-implants, Surface modification, Material engineering, Bibliometric analysis, VOS viewer,

\section{Introduction}

An engineered medical device to replace a missing or damaged biological structure is known as an implant. Human knee joints are facing numerous problems including wear, damage, and accidents. Total knee replacement surgery can improve quality of life in cases where repair of the knee is impossible. A knee implant is placed in the knee joint in cases of total knee replacement. knee implants are often used subjected to wear and corrosion and ultimately lead to poor performance, pain, and wastage of money. Similarly, various types of surface treatments and surface coatings can be conducted on knee implants to improve their competency to be used as a material for knee-implants. Material engineering and surface engineering can play a significant role in the development of new types of knee implants; and in enhancing the performance of knee implants.

The surface coating can improve the properties of steel knee implants by using Nanocoatings (Shivendra Kumar, Meenakshi, and Ramana, 2019); Sol-gel coating Surface modification of knee implants". (Balestriere et al., 2020)(Ballarre et al., 2012)(Ballarre et al., 2013)(Ballarre and Ceré, 2018) Silver coating (Devasconcellos et al., 2012); Nanostructured Forsterite (Mg2SiO4) coating (Kheirkhah et al., 2015); Hydroxyapatite/hydroxyapatite-magnesium double-layer coatings (Rezaei et al., 2020)(Sutha et al., 2015); (Shibli and Jayalekshmi, 2008).

Significant reduction of polyethylene wear can be possible by using Oxidised Zirconium as a femoral component material (Anderson et al., 2017)(DesJardins, Burnikel, and LaBerge, 2008)(Ezzet et al., 2004)(Ezzet et al., 2012). However, it is still controversial that whether the Oxidised Zirconium can demonstrate significant tribological benefits (Garrett et al., 2010)(Gascoyne et al., 2016). Oxidized zirconium total Knee replacements are superior and successful in a short period (Glover et al., 2018a) mid and long periods (Glover et al., 2018b).

The silver coating can enhance the performance of Titanium knee implants (Bitika, Uzuna, and Keçika, 2013). Increasing surface roughness (Elias et al., 2005)(Jemat et al., 2015) and thickness of Titanium oxide layer are possibilities for increasing biocompatibility of Titanium-based implants (Elias et al., 2005).

Surface coating especially the Cryogenic and Coating treatments can have a significant effect on the Wear and Friction of knee implants (Deenoi and Dechjarern, 2019). Stem cell-coated titanium implants can be used for the partial joint resurfacing of the knee (Frosch et al., 2006). Acid-etched surface-modification and a surface coating of Titanium implant was the most preferable way of increasing surface roughness (Jemat et al., 2015)(Doe et al., 2020). Antibacterial properties are an important factor in the success of implants and the antibacterial activity of Titanium implants by surface modification of Titanium with polydopamine and silver (Choi et al., 2019).

Various types of mechanical, chemical and electrochemical surface preparation methods like electrolytic polishing and ultrasonic cleaning can resist the corrosion of steel implants and reduce the breakdown potential (Ahmadian, Danaee and Golozar, 2013)(Ahmadian, Danaee and Golozar, 2014)(Irving Jr., 1985). Nanocoatings can be an ideal strategy for reducing wear in steel knee implants (Shivendra Kumar, Meenakshi, and Ramana, 2019). Similarly, Sol-gel coating can enhance the anticorrosive and surface performance of stainless steel 
(Balestriere et al., 2020)(Ballarre et al., 2012)(Ballarre et al., 2013)(Ballarre and Ceré, 2018) Silver coating on the implants (Devasconcellos et al., 2012);

This bibliometric analysis will be a useful platform for future researchers by realizing the top researchers, organizations, and countries involved in research regarding surface coating knee implants. This article is arranged into four sections. The first section is the introduction, followed by the discussion of the methodology by which the research was conducted. The third section deals with results and discussion. The fourth section deals with the conclusion. The following research objectives and research questions were framed for conducting bibliometric analysis systematically.

\subsection{Research Objectives}

a) To consolidate the literature regarding surface coating knee implants

b) To find out the trends related to research in surface coating knee implants

\subsection{Research Questions}

a) Who are the active researchers working on surface coating knee implants?

b) Which are the main organizations and countries working on surface coating knee implants?

c) Which are the main journals related to surface coating knee implants?

\section{Research Methodology}

Scopus files had been used for this article. For the article selection, the Boolean used was TITLE (Surface knee implant) on 26/02/2021. All the tables in this paper were created by using Microsoft Excel and VOS Viewer. Grammarly was used for spelling and grammar checks. Mendeley was used for article review and citation. This paper had been inspired by bibliometric analysis in its presentation style, analysis, and methodology from the works (Farhat et al., 2013; Liao et al., 2016; Kolkailah et al., 2019; Rodríguez-Padial et al., 2019; Tran et al., 2019; Ullah et al., 2019; Shahid et al., 2020).

\section{Results and discussion}

\subsection{Results}

This first round of search produced an outcome of 1436 documents, in 15 languages, out of which 1337 documents were in English. The classification of document categories is shown in Figure 1. For improving the quality of the analysis, we had selected only the peer-reviewed articles and all other documents had not been considered. Thus after using filters "Article" and "English" the second round search produced an outcome of 966 English articles (both open access and others). This paper had used all English articles to conduct bibliometric analysis and visualization using VOS Viewer. The English research articles in this domain since 1955 had been shown in Figure 2.

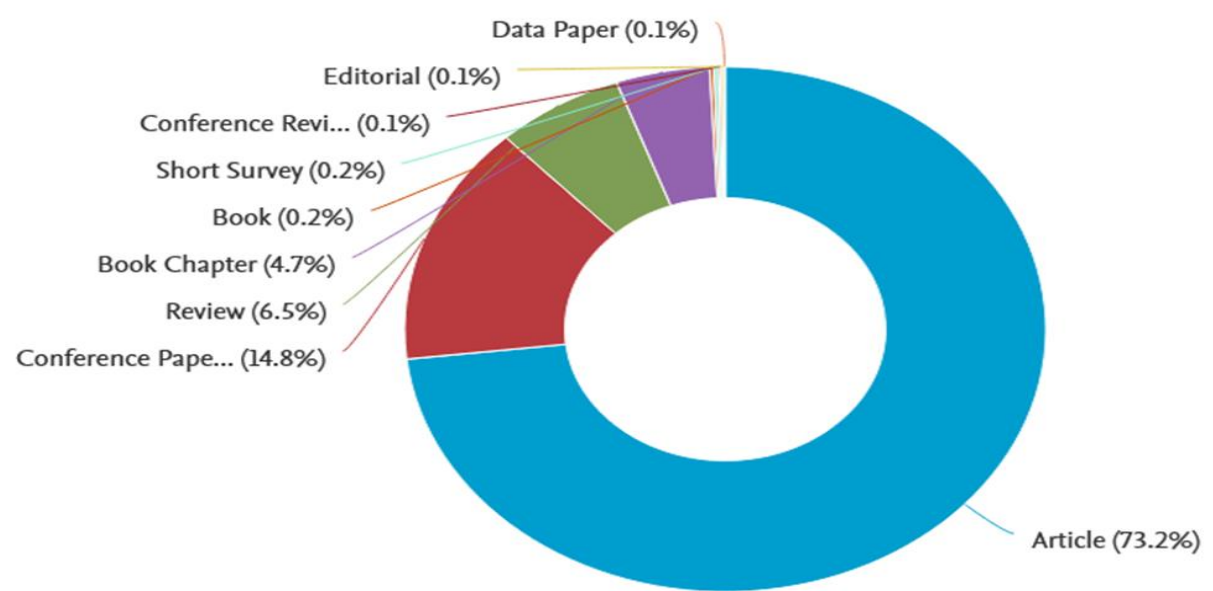

Figure 1: Classification of the documents on "Surface coating of knee implants", Source: www.scopus.com 


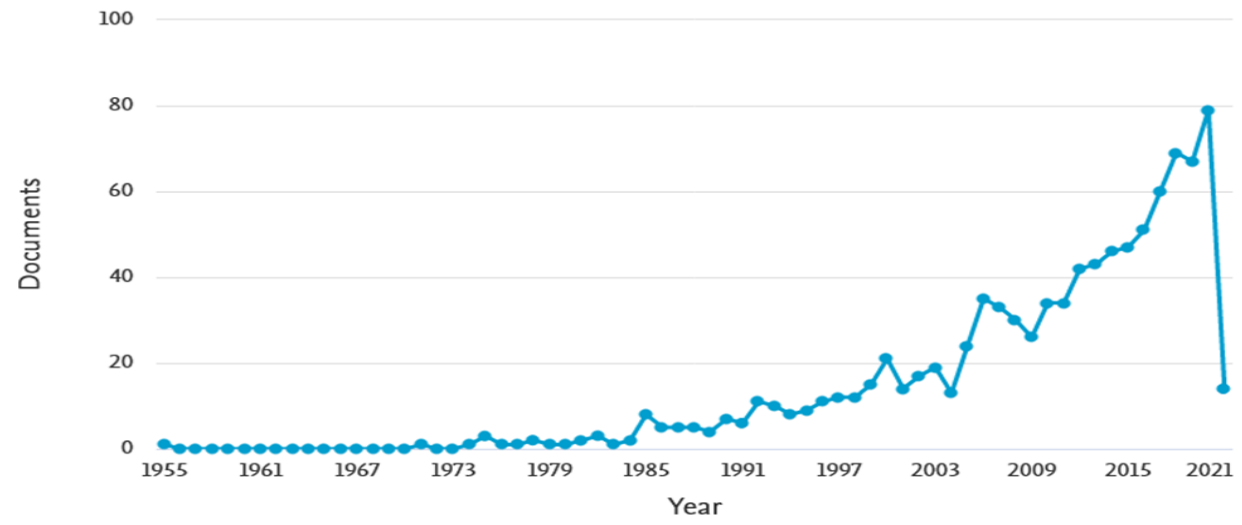

Figure 2: Period wise publication of articles, Source: WWW.scopus.com

Co-authorship analysis of top authors had been shown in figure 3. For a better presentation of the analysis, the parameters used were the minimum number of documents of an author as six and the minimum number of citations of authors as one. This combination plotted the map of 28 authors, in 21 clusters. The overlay visualization map of co-authorship analysis plotted in Figure 3, points out the major researchers with their strong co-authorship linkages and clusters involved.

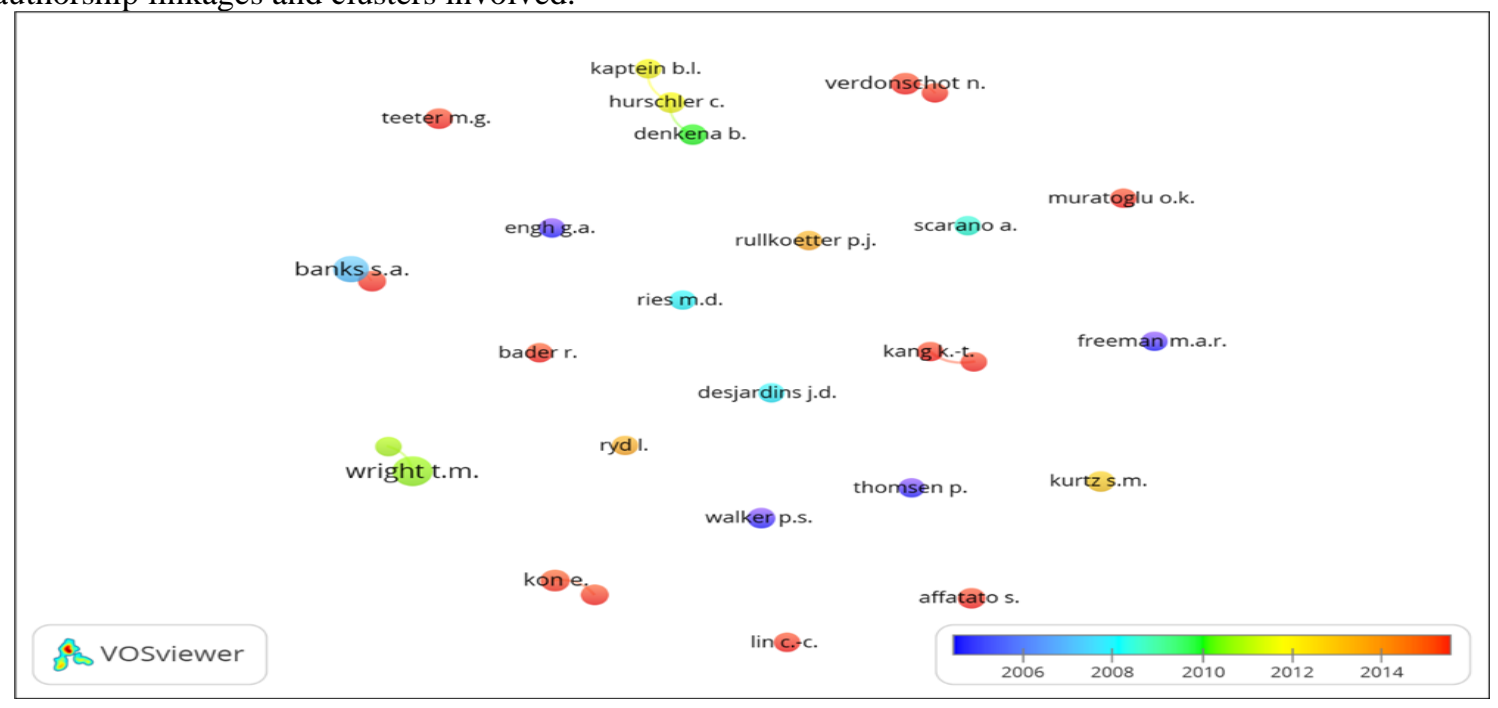

Figure 3: Co-authorship analysis on basis of authors

The citation analysis of top authors had been shown in table 1, along with co-authorship links. For the citation analysis, the parameters used were the minimum number of documents of an author as one and the minimum citations of an author as one.

Table 1: Highlights of most active authors

\begin{tabular}{|c|r|r|r|r|r|}
\hline Description & Authors & Documents & Citations & $\begin{array}{r}\text { Average } \\
\text { citations per } \\
\text { documents }\end{array}$ & $\begin{array}{r}\text { Link } \\
\text { strength }\end{array}$ \\
\hline $\begin{array}{l}\text { Authors with the } \\
\text { highest publication } \\
\text { and co-authorship } \\
\text { links }\end{array}$ & Wright T.M. & & & & \\
\hline $\begin{array}{l}\text { Authors with the } \\
\text { highest citations }\end{array}$ & Jacobs J.J. & 5 & 411 & 27.4 & 64 \\
\hline
\end{tabular}

In Co-occurrence analysis, we had used all keyword analyses, by keeping the minimum number of occurrences of a keyword as 100. This combination plotted the map of 35 thresholds, in three clusters. The overlay visualization of co-occurrence analysis of keywords has been shown in Figure 4. 


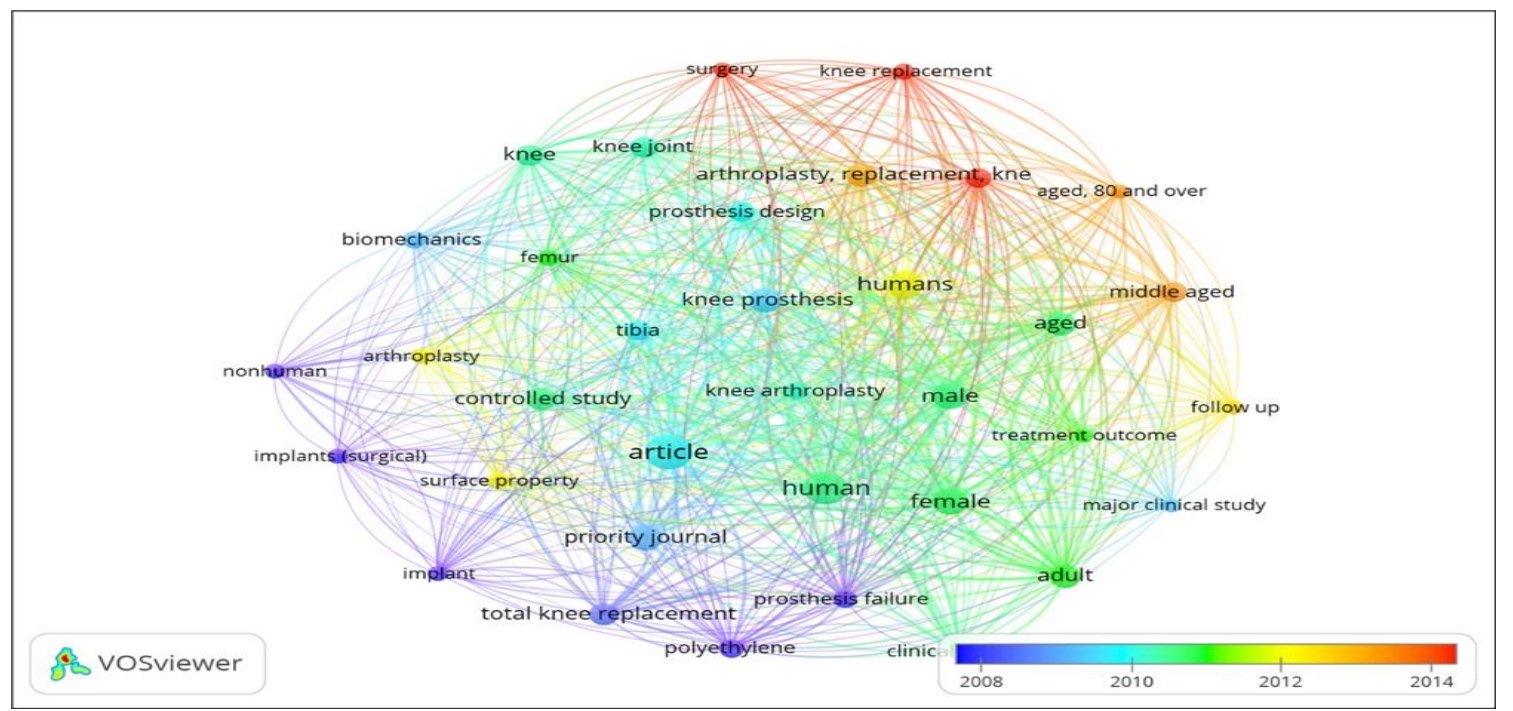

Figure 4: Co-occurrence analysis on basis of all keywords

The leading organizations engaged in research on "Surface modification of knee implants" had been found out by the volume of publications and citation analysis, the parameters used are the minimum number of documents of an organization as one and the minimum number of citations of organizations as one. The leading organization in the research regarding "Surface modification of knee implants"', with the highest number of publications and citations, was the Hospital for Special Surgery, United States of America (Refer to table 2).

\begin{tabular}{|c|c|c|c|c|}
\hline \multicolumn{1}{|c|}{ Table 2: Highlights of the most active organization } \\
\hline Organizations & Country & $\mathrm{s}$ Document & $\begin{array}{c}\text { Citatio } \\
\mathrm{ns}\end{array}$ & $\begin{array}{l}\text { Average } \\
\text { Citations } \\
\text { per } \\
\text { document }\end{array}$ \\
\hline Hospital for Special Surgery & $\begin{array}{c}\text { United States } \\
\text { of America }\end{array}$ & 32 & 851 & 23.8 \\
\hline
\end{tabular}

Co-authorship analysis of the countries engaged in the research on "Surface modification of knee implants" had been shown in Figure 5. The overlay visualization map of co-authorship analysis plotted in Figure 5, points out the main countries with their strong co-authorship linkages and clusters involved.

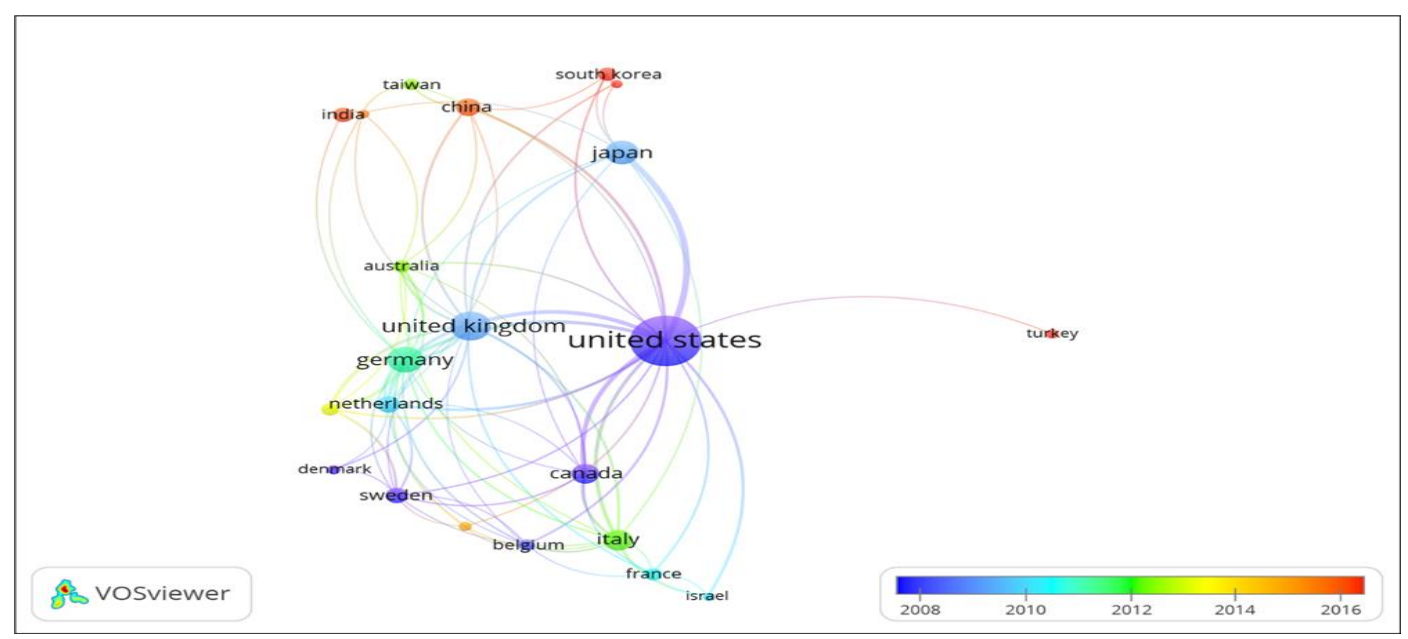

Figure 5: Co-authorship analysis on basis of countries

The citation analysis of top countries had been shown in table 3, along with co-authorship links. For the citation analysis, the parameters used were the minimum number of documents of a country as one and the minimum citations of the country as one.

Table 3: Highlights of Active Countries

\begin{tabular}{|l|l|l|l|c|}
\hline Description & Country & Documen & Citation & $\begin{array}{c}\text { Link } \\
\text { strength }\end{array}$ \\
\hline
\end{tabular}


The country with the highest publication, links,

United States of

America and citations

334

9826

104

The most active countries in this research domain were the United States of America with the highest number of publications, co-authorship links, and citations.

Link analysis and citation analysis were used to identify the most active journal in this research domain. We have taken the parameters of the minimum number of documents of a journal as one and the minimum number of citations of a journal as one for the link analysis and citation analysis. Highlights of the most active and relevant journals related to "Surface coating of knee implants" are shown in table 4 . Table 4 shows the journal activity of this research domain through parameters of publication volume, citations, and co-authorship linkages.

Table 4: Analysis of journal activity

\begin{tabular}{|c|c|c|c|c|c|}
\hline Description & Journal details & Documents & Citations & $\begin{array}{c}\text { Average } \\
\text { citations } \\
\text { per } \\
\text { documents }\end{array}$ & Links \\
\hline $\begin{array}{c}\text { Journal with the } \\
\text { highest publications } \\
\text { and co-authorship } \\
\text { links }\end{array}$ & $\begin{array}{c}\text { Journal of } \\
\text { Arthroplasty }\end{array}$ & 56 & 1178 & 21 & 102 \\
\hline $\begin{array}{l}\text { Journal with the } \\
\text { highest citations }\end{array}$ & $\begin{array}{l}\text { Journal of } \\
\text { Bone and Joint } \\
\text { Surgery }\end{array}$ & 23 & 2141 & & \\
\hline
\end{tabular}

From the above discussion regarding the bibliometric patterns in the research regarding surface modification of knee implants, this research had observed a gradual increase in research interest regarding surface modification of knee implants from the starting of the millennium and the momentum is going on positively. This points out the relevance and potential of this research domain (Refer to Figure 2). The most active authors in this research domain were Wright T.M. and Jacobs J.J with the highest publication, and co-authorship links; and citations respectively (Refer to table 1). The overlay analysis of top countries researching surface modification of knee implantations indicates that the United States of America was the leading country relating to the highest number of publications citations, co-authorship links (Refer to figure 5). The top journals of this research domain were identified as the Journal of Arthroplasty with the highest number of publications and links; and the Journal of Bone and Joint Surgery with the highest citations. From these wide sources of information, researchers can focus on top journals where they can identify the most relevant and highly cited articles regarding surface modification of knee implants.

\section{Conclusion}

The knee implant was an interesting research domain and the most active journals related to this research domain were the Journal of Arthroplasty and Journal of Bone and Joint Surgery. The most active country was the United States of America. The leading organization engaged in research regarding knee implants was the Hospital for Special Surgery of the United States of America. The most active authors who had made valuable contributions related to surface modification of knee implants were Wright T.M. and Jacobs J.J. This research domain offers a new avenue for researchers and future research can be on innovations in surface modification of knee implants.

\section{References}

1. Alexandru, G. et al. (2012) 'Heat treatments influence on corrosion resistance of some new dental cobalt alloys', Solid State Phenomena. Timisoara: Trans Tech Publications Ltd, 188, pp. 93-97. doi: 10.4028/www.scientific.net/SSP.188.93.

2. Al-Hasani, F. J. (2019) 'Studying the effect of cobalt percentage on the corrosion rate of sintered titanium dental implants', in Haider A.J. Jabur A.R., S. C.-T. V. G. (ed.) AIP Conference Proceedings. American Institute of Physics Inc. doi: 10.1063/1.5138497.

3. Al-Imam, H. et al. (2016) 'Cobalt release and complications resulting from the use of dental prostheses', Contact Dermatitis. Blackwell Publishing Ltd, 75(6), pp. 377-383. doi: 10.1111/cod.12649.

4. Berriau, T., Choudat, D. and Brochard, P. (1984) 'Cutaneous allergies to nickel, chromium and cobalt in dental mechanics [ALLERGIES CUTANEES AU NICKEL, AU CHROME ET AU COBALT CHEZ LES PROTHESISTES DENTAIRES]', Archives des Maladies Professionnelles de Medecine du Travail et de Securite Sociale, 45(6), pp. 464-465. Available at: https://www.scopus.com/inward/record.uri?eid=2-s2.0-

0021676203\&partnerID=40\&md5=1f0a2b559e5e651717a3639fbb4162e5. 
5. De França, D. G. B. et al. (2015) 'Influence of CAD/CAM on the fit accuracy of implant-supported zirconia and cobalt-chromium fixed dental prostheses', Journal of Prosthetic Dentistry. Mosby Inc., 113(1), pp. 22-28. doi: 10.1016/j.prosdent.2014.07.010.

6. Farhat, T. et al. (2013) 'Research in congenital heart disease: A comparative bibliometric analysis between developing and developed countries', Pediatric Cardiology, 34(2), pp. 375-382. doi: 10.1007/s00246-012-0466-6.

7. Harris, R. and Lossin, C. (1971) 'The use of cobalt chromium alloy and titanium endosseous dental implants', Australian Dental Journal, 16(2), pp. 94-108. doi: 10.1111/j.1834-7819.1971.tb02312.x.

8. Klawitter, J. J., Weinstein, A. M. and Peterson, L. J. (1977) 'Fabrication and Characterization of PorousRooted Cobalt-Chromium-Molybdenum (Co-Cr-Mo) Alloy Dental Implants', Journal of Dental Research, 56(5), pp. 474-480. doi: 10.1177/00220345770560050501.

9. Kolkailah, A. A. et al. (2019) 'Bibliometric Analysis of the Top 100 Most Cited Articles in the First 50 Years of Heart Transplantation', American Journal of Cardiology. Elsevier Inc., 123(1), pp. 175-186. doi: 10.1016/j.amjcard.2018.09.010.

10. Liao, J. et al. (2016) 'The most cited articles in coronary heart disease: A bibliometric analysis between 1970 and 2015', International Journal of Cardiology. Elsevier Ireland Ltd, 222, pp. 1049-1052. doi: 10.1016/j.ijcard.2016.08.002.

11. Lin, W.-S. et al. (2020) 'CAD-CAM cobalt-chromium surgical template for static computer-aided implant surgery: A dental technique', Journal of Prosthetic Dentistry. Mosby Inc., 123(1), pp. 42-44. doi: 10.1016/j.prosdent.2019.04.014.

12. Peterson, L. J., McKinney, R. V and Pennel, B. M. (1978) 'Two year evaluation of perous rooted cobaltchromium dental implants', Journal of Dental Research, 57(spec. A), p. No. 734. Available at: https://www.scopus.com/inward/record.uri?eid=2-s2.0$0017838402 \&$ partnerID $=40 \& \mathrm{md} 5=89 \mathrm{e} 4104671 \mathrm{aeb} 76 \mathrm{~d} 00 \mathrm{dbdc} 2 \mathrm{bfa} 368535$.

13. Ren, F., Zhu, W. and Chu, K. (2017) 'Fabrication and evaluation of bulk nanostructured cobalt intended for dental and orthopedic implants, Journal of the Mechanical Behavior of Biomedical Materials. Elsevier Ltd, 68, pp. 115-123. doi: 10.1016/j.jmbbm.2017.01.039.

14. Rodríguez-Padial, L. et al. (2019) 'Trends and Bibliometric Impact of Research Grants of the Spanish Society of Cardiology/Spanish Heart Foundation (2007-2012) [Evolución e impacto bibliométrico de las becas de la Sociedad Española de Cardiología/Fundación Española del Corazón en el periodo 20072012]', Revista Espanola de Cardiologia. Ediciones Doyma, S.L., 72(12), pp. 1012-1019. doi: 10.1016/j.recesp.2018.08.013.

15. Shahid, I. et al. (2020) 'Characteristics of highly cited articles in heart failure: A bibliometric analysis', Future Cardiology. Future Medicine Ltd., 16(3), pp. 189-197. doi: 10.2217/fca-2019-0016.

16. Tran, B. X. et al. (2019) 'The current research landscape of the application of artificial intelligence in managing cerebrovascular and heart diseases: A bibliometric and content analysis', International Journal of Environmental Research and Public Health. MDPI AG, 16(15). doi: 10.3390/ijerph16152699.

17. Ullah, S. et al. (2019) 'Publication trends of Pakistan Heart Journal: A bibliometric study', Library Philosophy and Practice. University of Idaho Library, 2019. Available at: https://www.scopus.com/inward/record.uri?eid=2-s2.0-

$85072911351 \&$ partnerID=40\&md5=c7b4ec3c78fbd1fed8e2e 7890fdef688. 